\title{
Výběr z nové právněhistorické literatury
}

\section{0}

DOSTALÍK, P. Nakládání s cizí věcí v soukromém právu. Praha: Leges, 2020. 152 s. ISBN 978-80-7502-398-8.

HORÁK, O. Brněnská normativní civilistika (postavy - projekty - polemiky). Praha: Wolters Kluwer ČR, 2020. 260 s. ISBN 978-80-7598-708-2.

HORÁK, Z. - SKŘEJPKOVÁ, P. (eds.). Pocta Jiřimu Rajmundu Treterovi. Praha: Leges, 2020. 448 s. ISBN 978-80-7502-439-8.

KLEŇOVÁ, V. Darovanie s príkazom v rímskom práve. Praha: Leges, 2020. 364 s. ISBN 978-80-7502-423-7.

KUKLÍK, J. Příběh československé ústavy 1920. I. Praha: Karolinum, 2020. 336 s. ISBN 978-80-246-4541-4.

STLOUKALOVÁ, K. - NOVÁK, M. - MACEK, D. - ULLMANN, J. Interpretační úskalí justiniánských Digest. Praha: Auditorium, 2020. 104 s. ISBN 978-80-87284-82-7.

TOMEŠ, I. Vzpomínky na 60 let v oboru sociální politiky, správy a práva 1955-2015. Praha: Karolinum, 2020. 206 s. ISBN978-80-2464-414-1.

TRETERA, J. R. - HORÁK, Z. Právní dějiny církví. Praha: Leges, 2020. 288 s. ISBN 978-80-7502-440-4.

\section{9}

BLAHO, P. - MLKVÝ, M. - VLADÁR, V. Držba v rímskom a kánonickom práve. Praha: Leges, 2019. 331 s. ISBN 978-80-7502-334-6.

DOSTALÍK, P. Condictiones. Ke kořenům bezdůvodného obohacení. Praha: Auditorium, 2019. 240 s. ISBN 978-80-87284-74-2.

GREGOR, M. Rímsky štát a právo za vlády cisára Augusta. Praha: Leges, 2019. 200 s. ISBN 978-80-7502-304-9.

MALATINSKÝ, M. Pred súdom národa? Retribúcia na Slovensku a Národný súd v Bratislave 1945-1947. Bratislava: PostScriptum, 2019. 288 s. ISBN 978-80-89567-93-5.

- Právněhistorická kniha roku 2019: 3. místo

MAYR-HARTING, R. Soustava občanského práva. (Repr.). Praha: Wolters Kluwer ČR, 2019. 1316 s. ISBN 978-80-7598-563-7.

MLKVÝ, M. Mechanizmy pôsobenia rímsko-kanonického práva v Anglicku. Bratislava: Wolters Kluwer, 2019. 152 s. ISBN 978-80-571-0024-9.

NOHEL, P. Výuka církevního práva na teologických a právnických fakultách v Českých zemich v letech 1918-1989. Praha: Karolinum, 2019. 185 s. ISBN 978-80-2464-148-5.

PODOLEC, O. Prvý slovenský parlament. Snem Slovenskej republiky a jeho legislativna činnost. Bratislava: Ústav pamäti národa, 2019. 455 s. ISBN 978-80-89335-79-4.

SCHELLE, K. Státoprávni aspekty revoluce 1848-1849 v rakouských, českých a uherských zemích. Ostrava: KEY Publishing, 2019. 166 s. ISBN 978-80-7418-312-6. 
SKŘEJPEK, M. Digesta seu Pandectae. Tomus II. Liber XVI-XXXV. Fragmenta selecta. Digesta neboli pandekty. Svazek II. Kniha XVI-XXXV. Vybrané části. Praha: Karolinum, 2019. 752 s. ISBN 978-80-2464-332-8.

- Cena Bedřicha Hrozného za tvůrčí počin udělované rektorem UK

STEINOVÁ, V. Pracovní poměr v letech 1945-1965. Brno: KEY Publishing, 2019. 249 s. ISBN 978-80-7418-327-0.

ŠOŠKOVÁ, I. a kol. Vznik Československej republiky a Slovensko. Praha: Leges, 2019. 250 s. ISBN 978-80-7502-338-4.

ŠOUŠA, J. Právní úprava amnestie v letech 1918-1953v českých zemích. Pelhřimov: Nová tiskárna Pelhřimov, 2019. 434 s. ISBN 978-80-7415-192-7.

- Právněhistorická kniha roku 2019: 3. místo

TOMÁŠEK, M. Právní systémy Dálného Východu. II. Praha: Karolinum, 2019. 365 s. ISBN 978-80-246-3897-3.

- Právněhistorická kniha roku 2019: 2. místo

VLADÁR, V. (ed). Perpauca terrena blande honori dedicata. Pocta Petrovi Blahovi k nedožitým 80. narodeninám. Trnava: Trnavská univerzita v Trnave, Právnická fakulta, 2019. 791 s. ISBN: 978-80-568-0313-4.

VOJÁČEK, L. - SCHELLE, K. - TAUCHEN, J. Dějiny Právnické fakulty Masarykovy univerzity 1919-2019. 1. a 2. díl. Brno: Masarykova univerzita, 2019. 575 s. ISBN 97880-210-9240-2 (1. díl). 692 s. ISBN 978-80-210-9241-9 (2. díl).

- Právněhistorická kniha roku 2019: 1. místo

doi: 10.14712/2464689X.2020.35 